\title{
Phylogenetic Relationships Between Mycoplasmas and Other Procaryotes Based upon the Electrophoretic Behavior of Their Ribosomal Ribonucleic Acids
}

\author{
MITCHELL E. REFF, ${ }^{1}$ ERIC J. STANBRIDGE, AND EDWARD L. SCHNEIDER
}

Department of Medical Microbiology, Stanford University School of Medicine, Stanford, California 94305; Department of Medical Microbiology, University of California, Irvine, College of Medicine, Irvine, California 92717; and National Institute on Aging, Gerontology Research Center, Baltimore, Maryland 21224

The migration of ribosomal ribonucleic acids (rRNA's) from bacteria, bacterial $\mathrm{L}$ forms, mycoplasmas, and acholeplasmas in nondenaturing and formamide gels has been examined. Mycoplasmal and acholeplasmal RNAs migrate in a pattern distinct from each other and from bacteria in nondenaturing gels. The differences observed appear to be mainly due to conformational differences in the molecules. When examined under denaturing conditions in formamide gels, the 23S RNAs of all organisms examined comigrated. The 16S RNAs of mycoplasmas and acholeplasmas comigrated and appear to be of a smaller molecular weight than bacterial 16S RNA. It is suggested that the differences observed are indicative of significant phylogenetic divergence between mycoplasmas and bacteria or bacterial $\mathrm{L}$ forms.

Mycoplasmas have been assigned to the taxonomic status of a class, Mollicutes, which is separate from bacteria and their $\mathrm{L}$ phase variants (4). The major distinguishing characteristics of mycoplasmas are their small size, lack of a cell wall, small genome, low guanine-pluscytosine $(\mathrm{G}+\mathrm{C})$ content of deoxyribonucleic acid (DNA), colonial morphology on agar, and dependence upon sterol for growth (24). Unfortunately, none of these characteristics is sufficient to clearly delineate mycoplasmas from $\mathrm{L}$ phase variants of bacteria, and the phylogenetic relationship of mycoplasmas with these organisms and other procaryotes is unclear.

In recent years evolutionarily conserved molecules have been used as probes to measure the phylogenetic relationships between organisms. Ribosomal ribonucleic acid (rRNA) has been particularly useful as a measure of the phylogenetic relationships among procaryotes, owing to its highly conserved nature (14). Techniques employed have included sucrose density gradient centrifugation (26), gel electrophoresis under nondenaturing conditions (10), determination of nucleotide sequence homology by nucleic acid hybridization (15), and fingerprinting and sequencing of oligonucleotide fragments $(27,28)$. These studies all confirm the highly conserved nature of bacterial rRNA.

Several investigators have reported that mycoplasmal rRNA differs from bacterial rRNA in

1 Present address: Department of Medical Microbiology and Molecular Genetics, Harvard Medical School, Boston, MA 02115. base composition $(7,22)$, sedimentation properties in sucrose gradients $(7,8,20)$, and electrophoretic mobility in polyacrylamide gels (6). In this present study the electrophoretic mobilities of rRNA's from mycoplasmas, acholeplasmas, bacteria, and a bacterial $L$ form were examined under nondenaturing and denaturing conditions. The significance of the results as they reflect phylogenetic differences between these organisms is discussed.

(This work was taken in part from a thesis submitted by M. E. R. in partial fulfillment of the requirements for the Ph.D. degree, Stanford University School of Medicine, Stanford, Calif., 1976.)

\section{MATERIALS AND METHODS}

Cultures. The microbial strains used in this study are listed in Table 1.

Growth of Cells. The basal medium used for growth of mycoplasmas and acholeplasmas consisted of $5 \%$ beef heart infusion (Difco), peptone (Difco), and $2.5 \%$ yeast extract, with $10 \%$ unheated horse serum (Irvine Scientific) added as a supplement for the growth of mycoplasma species and 100 $\mathrm{U}$ of penicillin per $\mathrm{ml}$ added to prevent bacterial contamination. The final $\mathrm{pH}$ of this medium and all the other media used was 7.6. The organisms were grown at $37^{\circ} \mathrm{C}$ for periods ranging from 2 to 4 days. Minor modifications of this medium were used for certain of the strains. Three mycoplasma species, Mycoplasma hyorhinis, $M$. hominis, and an unclassified strain, Mycoplasma 70-159 (representing isolates from human and animal hosts), and four acholeplasma species, Acholeplasma laidlawii, A. gran- 
TABLE 1. List of strains of microorganisms used

\begin{tabular}{llc}
\hline \multicolumn{1}{c}{ Organism } & \multicolumn{1}{c}{ Strain } & Source $^{a}$ \\
\hline Escherichia coli & CDK103 & 1 \\
Streptococcus pneumoniae & H33 & 1 \\
Streptococcus faecalis & ATCC 23241 & 2 \\
Streptococcus faecalis & ATCC 23242 & 2 \\
$\quad$ (L phase variant) & SB168 & 1 \\
Bacillus subtilis & TC20 & 3 \\
Mycoplasma hyorhinis & ATCC 23114 & 2 \\
Mycoplasma hominis & 70-159 & 3 \\
Mycoplasma sp. & PG8 & 4 \\
Acholeplasma laidlawii & Friend & 5 \\
Acholeplasma granularum & PG49 & 5 \\
Acholeplasma modicum & 19-L & 5 \\
Acholeplasma oculi & Stanford & 5 \\
\hline
\end{tabular}

a Sources: (1) E. Lederberg, Stanford University School of Medicine, Stanford, Calif.; (2) American Type Culture Collection, Bethesda, Md.; (3) E. Stanbridge, University of California, Irvine, Calif.; (4) National Collection of Type Cultures, London, England; (5) G. Kenny, University of Washington, Seattle, Wash.

ularum, A. oculi, and A. modicum, were used for these studies.

Streptococcus faecalis and Streptococcus pneumoniae were grown at $37^{\circ} \mathrm{C}$ in brain heart infusion. Escherichia coli was grown at $37^{\circ} \mathrm{C}$ in Davis minimal medium (9) supplemented with $0.5 \%$ glucose. Bacillus subtilis was grown at $37^{\circ} \mathrm{C}$ in Oxoid nutrient broth no. 2. S. faecalis $\mathrm{L}$ form variant was grown at $37^{\circ} \mathrm{C}$ in brain heart infusion, supplemented with 0.5 $M$ sucrose, $10 \%$ heat-inactivated horse serum, and $250 \mathrm{U}$ of penicillin per $\mathrm{ml}$.

Labeling of cells. Cells were labeled with either 5 $\mu \mathrm{Ci}$ of $\left[{ }^{3} \mathrm{H}\right]$ uridine per $\mathrm{ml}$ or $0.4 \mu \mathrm{Ci}$ of $\left[{ }^{14} \mathrm{C}\right]$ uridine per $\mathrm{ml}$ (Schwarz/Mann), with the exception of $M$. hominis, which was labeled with $5 \mu \mathrm{Ci}$ of $\left[{ }^{3} \mathrm{H}\right]$ uracil per ml (Schwarz/Mann). The bacteria were labeled in their growth media for 6 to $12 \mathrm{~h}$. The mycoplasmas and acholeplasmas were labeled by growing the organisms in 200 to $400 \mathrm{ml}$ of medium, pelleting by centrifugation, and resuspending in $50 \mathrm{ml}$ of labeling medium for 12 to $24 \mathrm{~h}$. The long labeling periods were used to insure the presence of radioisotope in mature $\mathrm{rRNA}$ rather than precursor rRNA (11): The labeling medium consisted of basal medium Eagle (Flow Laboratories) supplemented with $10 \%$ horse serum, $2 \mathrm{mM}$ glutamine, $N$-2-hydroxyethyl piperazine- $N^{\prime}$-2-ethanesulfonic acid buffer (Calbiochem), and $10 \mu \mathrm{g}$ of thymidine, guanosine, and adenosine per $\mathrm{ml}$, respectively (Calbiochem). A. oculi was labeled in the above medium plus $1 \%$ yeast extract. $M$. hominis was labeled in the above medium plus $1 \%$ yeast extract and $1 \%$ arginine with the $\mathrm{pH}$ adjusted to 6.5 . $S$. faecalis $\mathrm{L}$ form variant was labeled in the above medium with heatinactivated horse serum plus $0.5 \%$ sucrose.

Extraction of rRNA. Ribosomal RNA was extracted at $40^{\circ} \mathrm{C}$ with phenol and sodium dodecyl sulfate (SDS) by the method of Cooper and Kay (2). All of the gram-positive bacteria were treated with $0.3 \%$ lysozyme for $15 \mathrm{~min}$ at $45^{\circ} \mathrm{C}$ to facilitate digestion of the cell wall. Polyvinyl sulfate was added at a final concentration of $20 \mu \mathrm{g} / \mathrm{ml}$ to the aqueous phase of the extraction mixture as an inhibitor of ribonuclease activity. RNA was precipitated from the final aqueous phase by addition of cold $0.8 \mathrm{M}$ sodium chloride and absolute ethanol at $-20^{\circ} \mathrm{C}$. After overnight incubation at $-20^{\circ} \mathrm{C}$ the mixture was centrifuged and the pellet was suspended in $3 \mathrm{M}$ sodium acetate and $5 \mathrm{mM}$ ethylenediaminetetraacetic acid (EDTA) to selectively precipitate high-molecularweight RNA and to remove residual DNA and 4 to 5S RNA. This solution was then centrifuged and the pellet was suspended in a small volume of $E$ buffer [0.04 M tris(hydroxymethyl)aminomethane, $0.02 \mathrm{M}$ sodium acetate, $0.001 \mathrm{M}$ EDTA] plus $0.5 \%$ SDS ( $\mathrm{pH}$ 7.8 ), and stored at $-70^{\circ} \mathrm{C}$. RNA concentration was measured by orcinol determination (23). All glassware used in the extraction was precleaned with chromic acid and heated at $300^{\circ} \mathrm{C}$ for $12 \mathrm{~h}$.

Polyacrylamide agarose gels. Polyacrylamide agarose gels were prepared by the method of Peacock and Dingman (16). RNA samples in E buffer were mixed with glycerol (final concentration $10 \%$ ) just prior to loading on top of the gel. Earlier experiments had shown that either coextraction of different rRNA's or their mixing just prior to electrophoresis yielded essentially the same results (19). The gels consisted of $2.6 \%$ acrylamide and $0.5 \%$ agarose. They were 9 to $10 \mathrm{~cm}$ long and $0.5 \mathrm{~cm}$ in diameter. The procedure for gel electrophoresis was that described by Loening (10). Samples were subjected to electrophoresis for $1.5 \mathrm{~h}$ at $5 \mathrm{~mA}$ per gel. After completion of the electrophoretic run the gels were fixed in $1 \mathrm{M}$ acetic acid for $15 \mathrm{~min}$, washed with water for $30 \mathrm{~min}$, frozen, and sliced with a gel slicer $(9$ slices $/ \mathrm{cm})$. Each slice was placed in a vial with scintillation fluid [2,5-diphenyloxazole-1,4-bis-(5phenyloxazolyl)benzene-toluene] plus 5\% Protosol tissue solubilizer (New England Nuclear Corp.), prewarmed to $37^{\circ} \mathrm{C}$. After overnight shaking at $37^{\circ} \mathrm{C}$, the vials were counted in a Tri-Carb liquid scintillation spectrometer (Packard Instrument Co., model 3003).

Formamide gel electrophoresis. Formamide gels were prepared by the method of Pinder et al.. (17) with the following modifications: $99 \%$ formamide (Matheson, Coleman, Bell) was deionized with mixed-bed ion-exchange resin (Bio-Rad Amberlite MB-1), filtered, and then buffered with $0.02 \mathrm{M}$ diethylbarbituric acid (barbital). The $\mathrm{pH}$ was adjusted to 9.0 with $1 \mathrm{~N}$ hydrochloric acid or $1 \mathrm{~N}$ sodium hydroxide. Acrylamide at final concentrations of 3.5 and $10 \%$ was prepared in barbital-buffered deionized formamide and filtered, and the $\mathrm{pH}$ was adjusted to 9.0. The gels consisted of a bottom plug of $1.5 \mathrm{~cm}$ of $10 \%$ acrylamide topped by a $9-\mathrm{cm}$ section of $3.5 \%$ acrylamide. The gels were $0.5 \mathrm{~cm}$ in diameter. RNA samples were dissolved in buffered formamide mixed with glycerol just prior to loading on top of the gel. The final concentration of glycerol was $40 \%$, a concentration needed to prevent mixing of the RNA sample with the buffered formamide overlay. A 1-cm column of buffered formamide was then layered on top of the sample, and a 1-cm column of 0.02 $M$ sodium chloride (the running buffer) was layered on top of the buffered formamide. The running 
buffer was recirculated between the top and bottom electrophoresis chambers during the entire run to prevent the development of $\mathrm{pH}$ gradient in the gels.

Samples were subjected to electrophoresis at 0.5 $\mathrm{mA}$ per gel for $15 \mathrm{~min}$, followed by $1 \mathrm{~mA}$ per gel for $12 \mathrm{~h}$. The entire run was conducted at $45^{\circ} \mathrm{C}$.

After completion of the electrophoretic run the gels were processed in a manner similar to the polyacrylamide-agarose gels. The gels were first stained with methylene blue after fixation in order to locate the rRNA bands.

\section{RESULTS}

Because of the difficulty inherent in reproducing migratory distances in different experiments, all measurements were based on the relative migration of double-labeled $\left({ }^{3} \mathrm{H} /{ }^{14} \mathrm{C}\right)$ samples within the same gel. To establish the reproducibility of the system, homologous rRNA's were labeled with $\left[{ }^{3} \mathrm{H}\right]$ - or $\left[{ }^{14} \mathrm{C}\right]$ uridine and subjected to coelectrophoresis in the same gel. The results of one such study (Fig. 1A) demonstrate the validity of this technique. In this and all subsequent figures, only those portions of the gels depicting the migrational patterns of $23 \mathrm{~S}$ and $16 \mathrm{~S}$ RNAs, respectively, are shown. In these particular studies 5S rRNA was not examined and, in fact, was removed during extraction at the $3 \mathrm{M}$ sodium acetate step.

In the nondenaturing gels, the rRNA's of all of the bacterial species studied comigrated with the exception of $B$. subtilis 23S RNA. A representative gel is illustrated in Fig. 1B. The electrophoretic profile of $B$. subtilis 23S RNA (data not shown) indicated that this major RNA species migrated slightly faster than the comparable 23S RNA molecules of other bacterial species. The rRNA's of $S$. faecalis and its $\mathrm{L}$ form variant also comigrated (Fig. 1C).

When mycoplasmal and bacterial rRNA's were subjected to electrophoresis in the same gel, complete separation of their respective 23S and $16 \mathrm{~S}$ peaks was observed. Both species of mycoplasmal rRNA migrated more slowly than comparable bacterial rRNA's (Fig. 2A). Separation of acholeplasmal 23S RNA was also accomplished (Fig. 2B), although the difference was not as great as that seen between mycoplasmal and bacterial rRNA's. In contrast to the migration of their 23S rRNA's, acholeplasmal and bacterial 16S RNA peaks had identical migration patterns. Finally, when mycoplasma and acholeplasma rRNA's were run together, neither $23 \mathrm{~S}$ nor $16 \mathrm{~S}$ peaks comigrated and, as illustrated in Fig. 3, the mycoplasmal rRNA's behaved as larger molecules.

When the rRNA's of the different mycoplasma and acholeplasma species were sub- jected to electrophoresis together, essentially the same pattern was observed. The rRNA's of the three different mycoplasma species comigrated with each other, as did the rRNA's of the four acholeplasma species (data not shown).

When the ribosomal RNAs were compared in formamide gels under conditions of apparent total denaturation, a different picture emerged. The 23S and 16S rRNA's of all of the bacterial species and the streptococcal L form comigrated. A single example is illustrated in Fig. 4A. When mycoplasmal rRNA was subjected to coelectrophoresis with bacterial rRNA, comigration of the 23S rRNA's occurred but separation of the $16 \mathrm{~S}$ species was obtained (Fig. 4B). In this case, unlike in the nondenaturing gels, the mycoplasmal 16S RNA migrated more rapidly than the bacterial species. Exactly the same picture was seen when acholeplasmal RNA was subjected to coelectrophoresis with bacterial RNA. Not surprisingly, mycoplasmal and acholeplasmal RNA comigrated under these conditions. Finally, under these denaturing conditions, the 23S and 16S rRNA's of all three mycoplasma species comigrated as did those of the four acholeplasma species (data not shown).

Apparent molecular weights of the various ribosomal RNAs were calculated from both nondenaturing and denaturing formamide gels. The calculations are based upon the hypothesis that the distance a molecule migrates in a polyacrylamide gel is inversely proportional to the logarithm of its molecular weight (10). E. coli rRNA's were used as standards in these calculations with presumptive molecular weights of $5.25 \times 10^{5}$ and $1.05 \times 10^{6}$ assigned to $16 \mathrm{~S}$ and $23 \mathrm{~S}$ RNA, respectively (5). These calculations are summarized in Table 2 . With the exception of $B$. subtilis 23S RNA in the nondenaturing gels, all of the bacterial rRNA's are normalized to these standards since they comigrate with $E$. coli rRNA. Of considerable interest are the differences observed in the apparent molecular weights of mycoplasmal and acholeplasmal rRNA in nondenaturing gels compared to denaturing formamide gels. As discussed further in Discussion, we believe these apparent molecular weight changes are due to conformation differences which are retained in nondenaturing gels but destroyed in warm formamide.

\section{DISCUSSION}

Nucleic acid hybridization and sequencing studies have demonstrated that substantial sequence homologies exist among the rRNA's of diverse species of bacteria $(15,25,27)$. In addition, the base composition of bacterial rRNA 

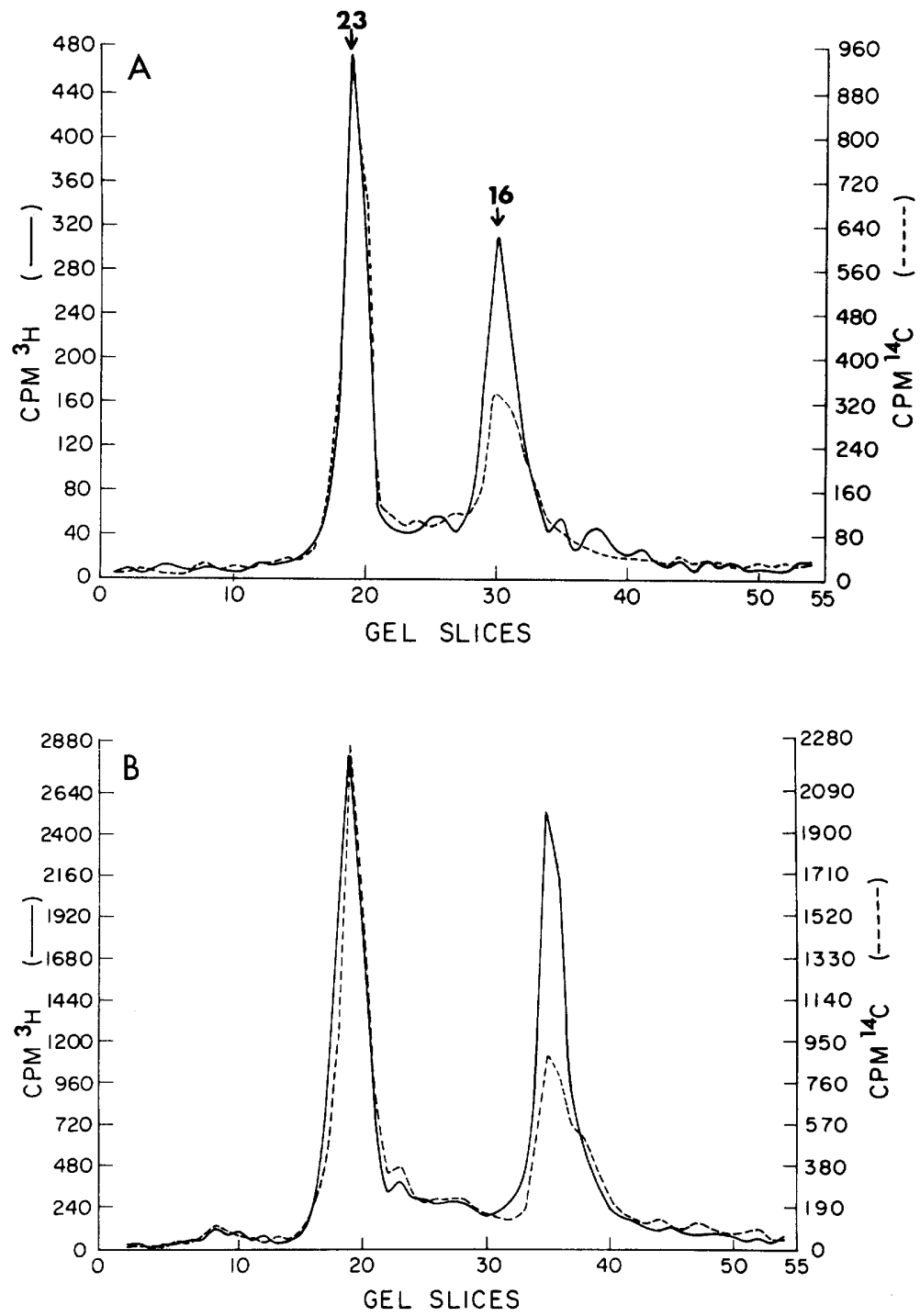

FIG. 1. (A) ${ }^{3} \mathrm{H}$ - and ${ }^{14} \mathrm{C}$-labeled rRNA of Streptococcus faecalis subjected to coelectrophoresis in a nondenaturing gel. Details of the electrophoretic procedure are outlined in the text. Comigration of both $23 S$ and $16 S$ rRNA peaks is illustrated. The direction of migration is left to right in all of the gel figures. The 23S and 16S peaks are indicated by arrows. In all of the following figures the $23 S$ and 16S peaks are in the same relative position to one another. Symbols: ${ }^{3} \mathrm{H}$-labeled $\mathrm{S}$. faecalis, $-;{ }^{14} \mathrm{C}$-labeled $\mathrm{E}$. coli, ----, (B) ${ }^{3} \mathrm{H}$-labeled rRNA of $S$. faecalis subjected to coelectrophoresis with ${ }^{14} \mathrm{C}$-labeled $r R N A$ of Escherichia coli in nondenaturing gel. Symbols: ${ }^{3} \mathrm{H}$-labeled $S$. faecalis, —_; ${ }^{14} \mathrm{C}$-labeled $\mathrm{E}$. coli, ..... (C) ${ }^{3} \mathrm{H}$-labeled $r R N A$ of $S$. faecalis $L$ form variant run with ${ }^{14} \mathrm{C}$-labeled rRNA of its parent bacterium in nondenaturing gel. Symbols: ${ }^{3} \mathrm{H}$-labeled $S$. faecalis $L$ form, —; ${ }^{14} \mathrm{C}$-labeled $S$. faecalis parent, -.-..

has been conserved (14). The conservation of base composition and sequence in rRNA's from a wide variety of bacteria presumably reflects the conservation of a unique conformation of the rRNA essential for functional ribosome assembly and ribosome function. Ribosomal reconstitution experiments creating functional ribosomes from heterologous rRNA and ribo- somal proteins support this hypothesis (13).

The conservation of conformation of procaryotic rRNA is also confirmed by the nondenaturing gel electrophoretic studies of Loening (10), which show only very small migrational differences in rRNA's from various bacteria and blue-green algae.

The migration of a single-stranded nucleic 


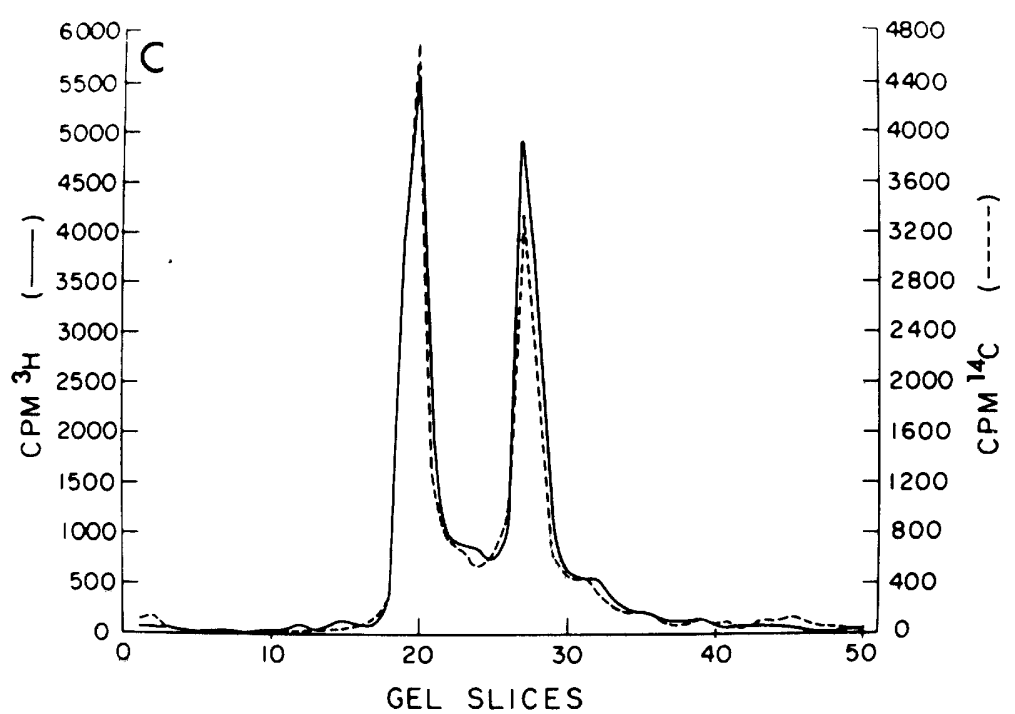

Fig. $1 C$.

acid in a nondenaturing gel is primarily dependent upon the conformation that the molecule assumes. The conformation is in turn dependent upon temperature, $\mathrm{pH}$, ionic strength, base sequence, and base composition. When comparing the migration of two rRNA's in a single gel under the same physical and chemical conditions, the variables responsible for migrational differences are reduced to base sequence, base composition, and/or molecular weight.

The comigration of rRNA's from diverse bacterial species and the one $L$ phase variant used in this study in both nondenaturing and denaturing gels indicates conservations of conformation and molecular weight and is in full agreement with the data indicating that base sequence and base composition have been conserved in bacterial rRNA. Although only four bacterial species were examined, they include gram-positive cocci, gram-negative rods, and gram-positive rods, and thus are representative of evolutionarily diverse mesophilic bacterial organisms (1). Two representative species of streptococci were included because there has been some discussion as to the phylogenetic relatedness of these organisms to acholeplasmas based upon the similarity between their respective lactate dehydrogenase systems (12).

Viewed from this standpoint, the differences seen in the migration in nondenaturing gels of rRNA from mycoplasmas, acholeplasmas, and bacteria strengthens the hypothesis that members of the class Mollicutes are phylogenetically distinct from bacteria or their $L$ phase variants. The differences seen in the migration of myco- plasmal and acholeplasmal RNA in nondenaturing gels indicate a degree of phylogenetic divergence between these two groups of organisms. This would seem to be a reasonable premise considering, among other properties, that acholeplasmas have a genome size twice as large as mycoplasmas (24). However, it is important to note that these represent conformational differences only, and when the RNAs are run in formamide gels they comigrate in a pattern different from that of the bacterial RNAs studied.

To clarify the role of molecular weight in the migration of rRNA in nondenaturing gels, the same rRNA's were subjected to electrophoresis under fully denaturing conditions in $99 \%$ formamide acrylamide gels at $45^{\circ} \mathrm{C}$. Formamide eliminates both base pairing and single-strand stacking in single-stranded RNA at room temperature (16). However, the presence of residual circular dichroism of single-stranded rRNA in formamide at room temperature is indicative of a preferred configuration which still exists under these conditions (16). We have found that the migration of rRNA in formamide gels at room temperature is different from its migration at $45^{\circ} \mathrm{C}$ (data not shown). Since singlestranded RNA in formamide at $45^{\circ} \mathrm{C}$ exhibits no circular dichroism, we believe the preferred configuration is abolished at this temperature. Under these conditions, where the secondary and tertiary structure of the rRNA is destroyed, the RNAs can all be assumed to be configurational homologs (17). Therefore, migration of molecules in gels that are configurational homologs is inversely proportional to the logarithm 

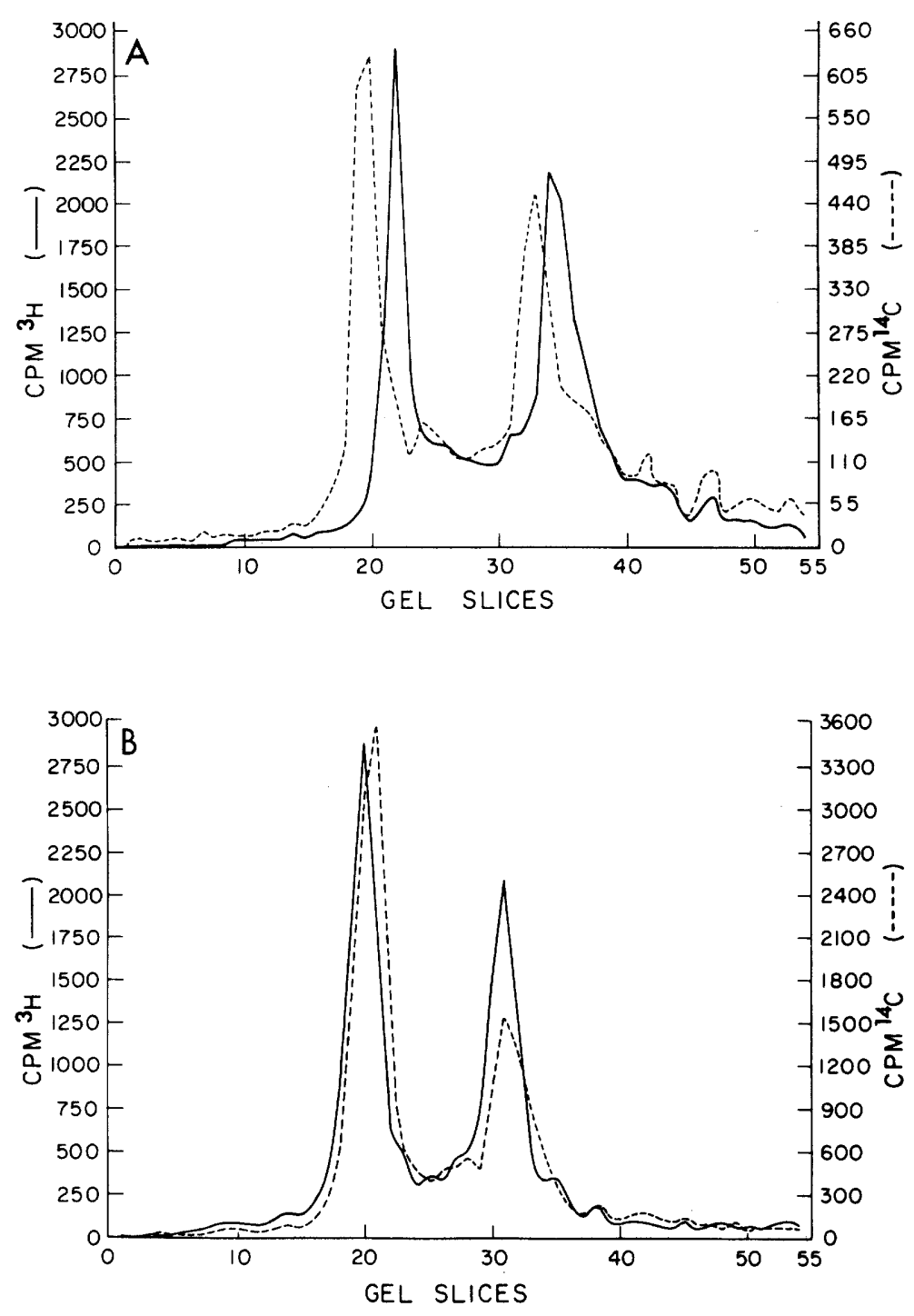

Fig. 2. (A) ${ }^{3} \mathrm{H}$-labeled rRNA of $S$. faecalis subjected to coelectrophoresis with ${ }^{14} \mathrm{C}$-labeled $r R N A$ of Mycoplasma hyorhinis in nondenaturing gel. Separation of both $23 S$ and $16 \mathrm{~S}$ peaks is apparent. Symbols: ${ }^{3} \mathrm{H}$ labeled S. faecalis, —; ${ }^{14} \mathrm{C}$-labeled M. hyorhinis, ...-. (B) ${ }^{3} \mathrm{H}$-labeled rRNA of Acholeplasma laidlawii subjected to coelectrophoresis with ${ }^{14} \mathrm{C}$-labeled rRNA of S. faecalis in nondenaturing gel. $16 S$ rRNAs comigrate, but there is a distinct separation between the $23 \mathrm{~S}$ peaks. Symbols: ${ }^{3} \mathrm{H}$-labeled A. laidlawii, —; ${ }^{14} \mathrm{C}$ labeled $\mathbf{S}$. faecalis, .....

of their molecular weight $(10,17)$.

The comigration of rRNA from diverse bacterial species and an $\mathrm{L}$ phase variant in formamide gels at $45^{\circ} \mathrm{C}$ indicates conservation of molecular weight, and is in full agreement with the data reporting conservation of base composition, base sequence, and conformation of bacterial rRNA.

The information derived from the formamide gel electrophoretic patterns of mycoplasmal, acholeplasmal, and bacterial rRNA's implies that the migrational differences seen in nondenaturing gels are primarily due to conformational differences in their rRNA's rather than to molecular weight. The apparent difference in the molecular weight of the 16S rRNA of mycoplasmas and acholeplasmas compared to bacteria would seem to indicate that a significant 


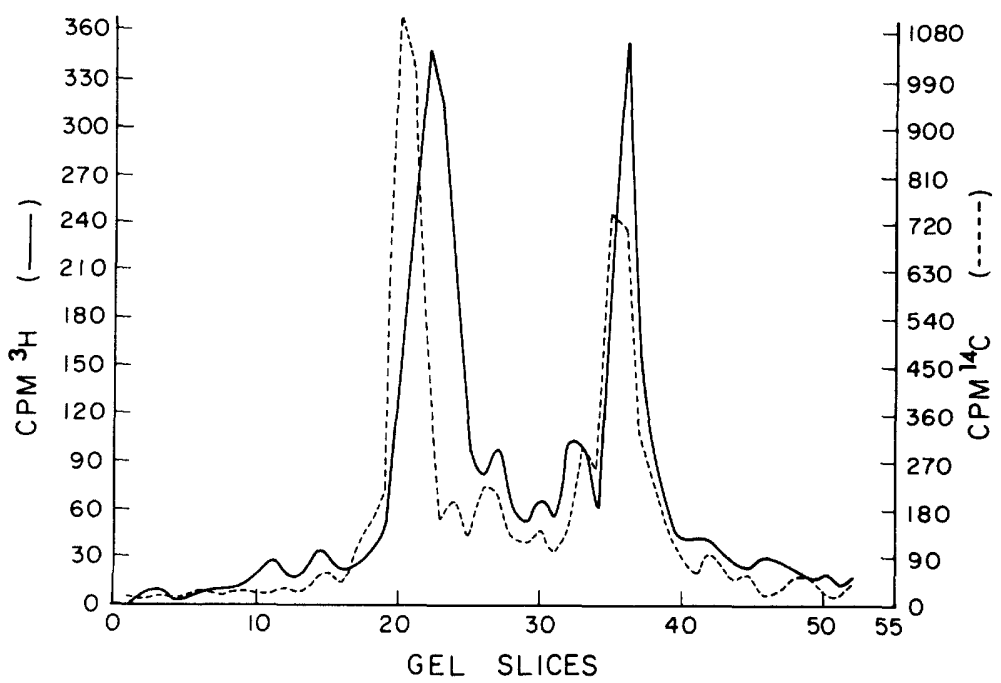

FIG. 3. ${ }^{3}$ H-labeled rRNA of A. laidlawii subjected to coelectrophoresis with ${ }^{14}$ C-labeled rRNA of $M$. hyorhinis in nondenaturing gel. Separation of both $23 S$ and $16 S$ peaks is apparent. Symbols: ${ }^{3} H$-labeled A. laidlawii, —; ${ }^{14}$ C-labeled $M$. hyorhinis, -..-.

TABLE 2. Molecular weights of the ribosomal RNAs

\begin{tabular}{lccc}
\hline \multicolumn{1}{c}{ Organism } & $\begin{array}{c}\text { Species } \\
\text { of } \\
\text { rRNA }\end{array}$ & $\begin{array}{c}\text { Apparent mol wt of rRNA } \\
\text { species calculated from } \\
\text { nondenaturing gels }\end{array}$ & $\begin{array}{c}\text { Mol wt of rRNA species } \\
\text { calculated from denatur- } \\
\text { ing gels }\end{array}$ \\
\hline $\begin{array}{l}\text { Streptococcus faecalis L phase variant } \\
\text { S. faecalis }\end{array}$ & $23 \mathrm{~S}$ & $1,050,000$ (standard) & $1,050,000$ \\
$\begin{array}{l}\text { S. pneumoniae } \\
\text { Escherichia coli }\end{array}$ & $16 \mathrm{~S}$ & 525,000 (standard) & 525,000 \\
Bacillus subtilis & & & $1,050,000$ \\
& $23 \mathrm{~S}$ & 983,000 & 525,000 \\
Mycoplasma spp. & $16 \mathrm{~S}$ & 525,000 & $1,050,000$ \\
& $23 \mathrm{~S}$ & $1,190,000$ & 513,000 \\
Acholeplasma spp. & $16 \mathrm{~S}$ & 555,000 & $1,050,000$ \\
& $23 \mathrm{~S}$ & $1,130,000$ & 513,000 \\
\hline
\end{tabular}

evolutionary gap exists between these organisms and bacteria and their $L$ phase variants.

Determination of the molecular weight of a macromolecular substance based upon its electrophoretic mobility in gels is dependent upon the total denaturation of the molecules. Since we found that rRNA migrates differently in formamide at room temperature than at $45^{\circ} \mathrm{C}$, we feel that other electrophoretic studies utilizing formamide to determine molecular weight at room temperature may have to be reevaluated $(3,7,21)$.

Although several distinguishing properties have been proposed as evidence for the taxonomic separation of members of the class Mollicutes from bacteria, most of them are shared with $\mathrm{L}$ forms of bacteria. These include lack of a cell wall, umbonate colonies on agar, and others. Lack of homology between the DNAs of mycoplasmas and bacteria, as measured by nucleic acid hybridization, has also been used as a major argument for their placement in a separate class. However, these claims are erroneous since homology studies using total DNA are applicable only to intraspecies, or closely related interspecies, differences. DNA-DNA hybridizations between unrelated bacterial species may show less than $1 \%$ homology (15).

This study is the first to use an evolutionarily conserved molecule, rRNA, to investigate the phylogenetic status of mycoplasmas. It shows that the rRNA from a stable $\mathrm{L}$ phase variant is 

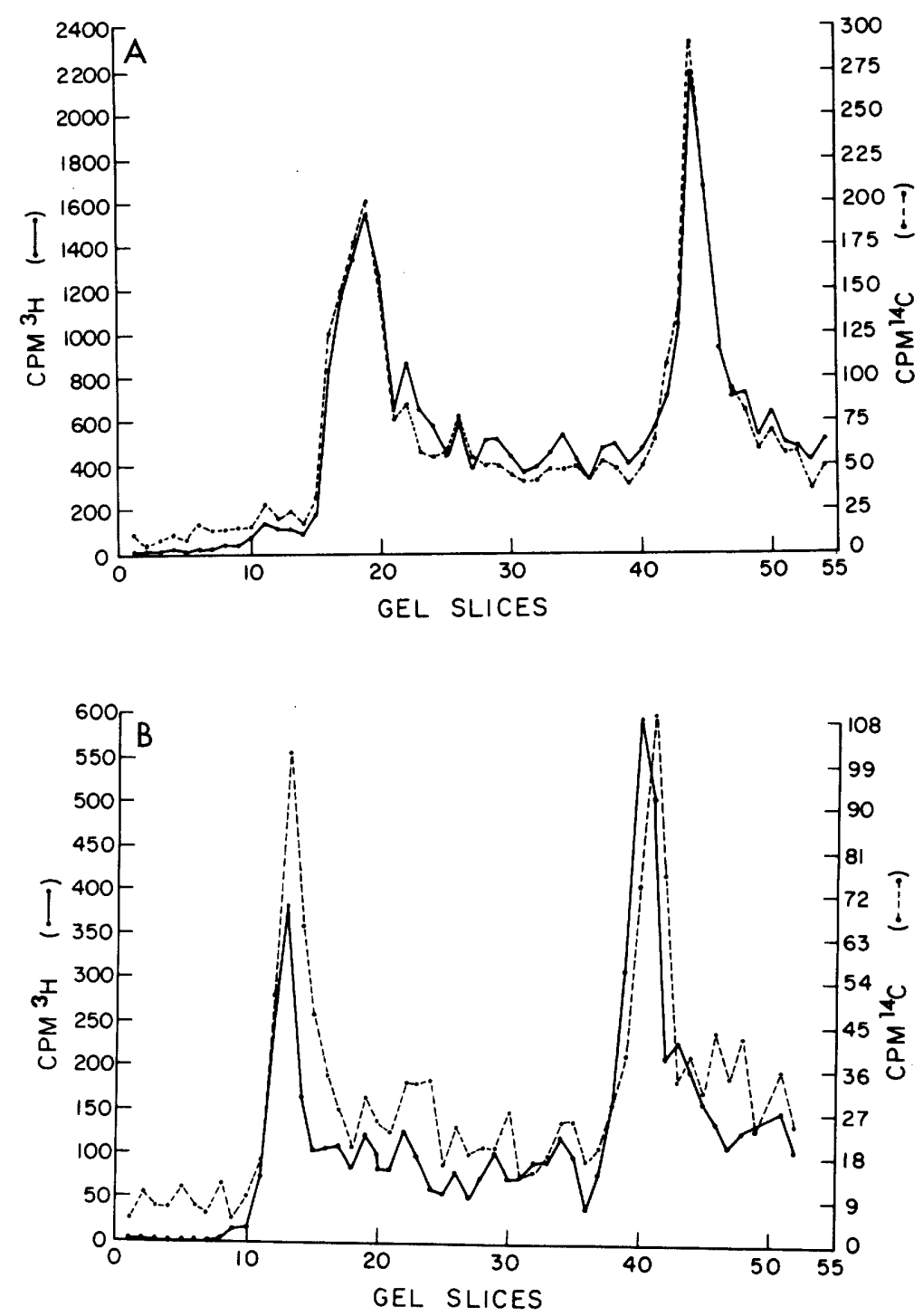

Fig. 4. (A) ${ }^{3} \mathrm{H}$-labeled rRNA of $S$. pneumoniae subjected to coelectrophoresis with ${ }^{14} \mathrm{C}$-labeled $r R N A$ of $E$. coli in a formamide gel. Details of the electrophoresis can be found in the text. Symbols: ${ }^{3} \mathrm{H}$-labeled $S$. pneumoniae, $\longrightarrow ;{ }^{14} \mathrm{C}$-labeled $\mathrm{E}$. coli, -.-.. (B) ${ }^{3} \mathrm{H}$-labeled $r R N A$ of $E$. coli subjected to coelectrophoresis with ${ }^{14} \mathrm{C}$-labeled $\mathrm{rRNA}$ of $M$. hyorhinis in a formamide gel. Symbols: ${ }^{3} \mathrm{H}$-labeled $\mathrm{E}$. coli, $-;{ }^{4} \mathrm{C}$-labeled M. hyorhinis, -....

identical to the parent bacterial rRNA in both conformation and molecular weight. In contrast, the rRNA's from acholeplasmas and mycoplasmas are different both in conformation and, in the case of 16S RNA, also in molecular weight from bacterial rRNA. This difference in rRNA between a stable bacterial $L$ phase and mycoplasmas or acholeplasmas suggests that a significant evolutionary gap exists between these seemingly similar organisms.

\section{ACKNOWLEDGMENTS}

We wish to thank Bill Raymond for his excellent technical assistance.

These studies were supported by Public Health Service Institutional Research Service Award GM 07276 from the National Institute of General Medical Sciences. Eric J. Stanbridge is a Leukemia Society of America Special Fellow.

\section{REPRINT REQUESTS}

Address reprint requests to: Dr. Eric J. Stanbridge, Uni- 
versity of California, Dept. of Medical Microbiology, College of Medicine, Irvine, CA 92717.

\section{LITERATURE CITED}

1. Buchanan, R. E., and N. E. Gibbons (ed.). 1974. Bergey's manual of determinative bacteriology, 8th ed. Williams and Wilkins Co., Baltimore.

2. Cooper, L. H., and J. E. Kay. 1969. Differential extraction of nuclear and cytoplasmic RNA from intact lymphocytes. Biochim. Biophys. Acta 174:503-512.

3. Duesberg, P. H., and P. K. Vogt. 1973. Gel electrophoresis of avian leukosis and sarcoma viral RNA in formamide: comparison with other viral and cellular RNA species. J. Virol. 12:594-599.

4. Edward D. G. ff., and E. A. Freundt. 1967. Proposal for Mollicutes as name of the class established for order Mycoplasmatales. Int. J. Sys. Bacteriol. 17:267-268.

5. Fellner, $P$. 1974. Structure of the $16 \mathrm{~S}$ and $23 \mathrm{~S}$ ribosomal RNAs in ribosomes, p. 169-191. In M. Nomura, A. Tissieres, and P. Lengyel (ed.), Cold Spring Harbor Monograph Series. Cold Spring Harbor Laboratory, Cold Spring Harbor, N.Y.

6. Harley, E. H., J. W. White, and K. R. Rees. 1973. The identification of different structural classes of nucleic acids by electrophoresis in polyacrylamide gels of different concentrations. Biochim. Biophys. Acta 229:253-263.

7. Johnson, J. D., and J. Horowitz. 1971. Characterization of ribosomes and RNAs from Mycoplasma hominis. Biochim. Biophys. Acta 24:262-279.

8. Kirk, R. G., and H. J. Morowitz. 1969. Ribonucleic acids of Mycoplasma gallisepticum strain A5969. Am. J. Vet. Res. 30:287-293.

9. Lederberg, J. 1950. Isolation and characterization of biochemical mutants of bacteria. Methods Med. Res. 3:5-22.

10. Loening, U. 1968. Molecular weights of ribosomal RNA in relation to evolution. J. Mol. Biol, 38:355-365.

11. Mangiarotti, G., D. Apirion, D. Schlessinger, and L. Silengo. 1968. Biosynthetic precursors of $30 \mathrm{~S}$ and $50 \mathrm{~S}$ ribosomal particles in Escherichia coli. Biochemistry 7:456-472.

12. Neimark, H. 1974. Implications of the phylogenetic relationship between acholeplasmas and lactic acid bacteria. INSERM 33:71-78.

13. Nomura, M., P. Traub, and H. Bechmann. 1968. Hybrid $30 \mathrm{~S}$ ribosome particles reconstituted from components of different bacterial origins. Nature (London) 219:793-798.
14. Pace, N. R. 1973. Structure and synthesis of the ribosomal ribonucleic acid of prokaryotes. Bacteriol. Rev. 37:562-603.

15. Pace, B., and L. L. Campbell. 1971. Homology of ribosomal ribonucleic acid of diverse bacterial species with Escherichia coli and Bacillus stearothermophilus. J. Bacteriol. 107:543-547.

16. Peacock, A. C., and C. W. Dingman. 1968. Molecular weight estimation and separation of ribonucleic acid by electrophoresis in agarose-acrylamide composite gels. Biochemistry 7:668-674.

17. Pinder, J. C., D. Z. Staynov, and W. B. Gratzer. 1974 Properties of RNA in formamide. Biochemistry 13:5367-5372.

18. Pinder, J. C., D. Z. Staynov, and W. B. Gratzer. 1974. Electrophoresis of RNA in formamide. Biochemistry 13:5374-5378.

19. Reff, M. E., and E. J. Stanbridge. 1976. Conformational differences in bacterial ribosomal RNAs in non-denaturing conditions. Nature (London) 260:724726.

20. Reich, P. R. 1967. Discussion. Ann. N.Y. Acad. Sci. 143:113.

21. Reijnder, S., P. Stoff, J. Swal, and P. Borst. 1973. Gel electrophoresis of RNA under denaturing conditions. Biochim. Biophys. Acta 324:320-333.

22. Ryan, J. L., and H. J. Morowitz. 1969. Partial purification of native rRNA and tRNA cistron from Mycoplasma sp. (Kid). Proc. Natl. Acad. Sci. U.S.A. 63:1282-1289.

23. Shatkin, A. J. 1969. p. 231-237. In K. Habel and N. P. Salzman (ed.), Fundamental techniques in virology. Academic Press Inc., New York.

24. Smith, P. F. 1973. The biology of Mycoplasmas. Academic Press Inc., New York.

25. Sogin, S. J., M. L. Sogin, and C. R. Woese. 1972. Phylogenetic measurement in prokaryotes by primary structural characterization. J. Mol. Evol. 1:173-184.

26. Taylor, M. M., J. E. Glasgow, and R. Storck. 1967. Sedimentation coefficients of RNA from $70 S$ and 80 S ribosomes. Proc. Natl. Acad. Sci. U.S.A. 57:164-169.

27. Woese, C. R., G. E. Fox, L. Zablen, T. Uchida, L. Boner, K. Peckham, B. L. Lewis, and D. Stahl. 1975. Conservation of primary structure in $16 \mathrm{~S}$ ribosomal RNA. Nature (London) 254:83-86.

28. Woese, C. R., M. L. Sogin, and L. A. Sutton. 1974 Prokaryote phylogeny. I. Concerning the relatedness of Aerobacter aerogenes to Escherichia coli. J. Mol. Evol. 3:293-299. 